\title{
THE ORIGIN AND DEVELOPMENT OF THE PRIVATIZATION RELATIONS IN RUSSIA: THE HISTORICAL AND LEGAL RESEARCH
}

Abstract: The article deals with the historical and legal study of the emergence and development of privatization relations in Russia. Specifically historical experience clearly demonstrates that the optimally chosen form of ownership largely determines the stability of the state and the effectiveness of its economic policy. The authors study the issues of the beginning of the privatization processes, the stages of privatization provides an analysis of the main regulatory legal acts regulating the privatization processes in various historical periods. The objective of the presented historical and legal research is the formation of a comprehensive scientific understanding of the emergence and development of legal regulation of privatization relations in Russia in various historical periods. This objective predetermined the choice of tasks that must be solved in the research process: to determine the moment of the beginning of the privatization processes in Russia; describe the main stages of privatization in Russia; to analyze the regulatory legal acts regulating the privatization processes at various stages; and identify trends in the legal regulation of privatization processes at the present stage. As a result of the study, the authors concluded that the privatization that took place in Russia at the end of the XX and beginning of the XXI centuries was a process of redistribution of public property in the interests of private individuals.

\footnotetext{
${ }^{1}$ Kazan Federal University University, 18 Kremlyovskaya St., Kazan, Republic Tatarstan, 420008, Department of Theory and History of State and Law.e-mail: 1ls2002@mail.ru, Tel.: 89874067905

${ }^{2}$ Kazan Federal University University,18 Kremlyovskaya St., Kazan, Republic Tatarstan, 420008, Department of Theory and History of State and Lawalshigabutdinova@yandex.ru. Tel.: 89178590002
} 
Keywords: privatization, privatization relations, property right, historical stage, state and municipal unitary enterprises.

\section{Introduction}

The relevance of the historical and legal study of the emergence and development of privatization relations in Russia is expressed in several aspects. The socio-economic aspect lies in the fact that privatization affects equally private and public interests. It should be noted that public law entities need to replenish the budget, as well as the development of economic relations, strive to increase the competitiveness of business entities. One of the main tasks of the state is to attract private investment and free itself from the burden of maintaining property, which requires significant costs from the owner. At the same time, private owners who have privatized state or municipal property want an absolute right for its disposal. The main task of entrepreneurs and businesses, in general, is to maximize profits from the use of privatized property.

The legislative aspect consists in the need to study the history of the legal regulation of privatization relations
192

in order to further improve legislation in this area and determine the main trends in the development of legislation. The enforcement aspect is determined by those tasks that are achieved through the privatization of state property. In particular, it is an increase in the efficiency of enterprises, reduction of government spending at the expense of taxpayers, progressive increase in budget revenues, gradual reduction of domestic and foreign debt, support to and development of competition, as well as the fight against monopolistic entities in the market, etc.

There are various definitions of the term "privatization", however, it can be stated that the literature provides two main approaches to the interpretation of this concept. According to the first approach, privatization is understood in a broad sense as "the transfer of authority from the state to private individuals" [1]. According to A. Kaidatizis, privatization is a "transfer process from "public" to "private" [2]. The second approach is a narrow understanding of privatization. It was reflected in article 217 of the Civil Code of the Russian Federation, where privatization refers to the transfer process property owned by the state or 
municipal property, into the ownership of citizens and legal entities in the manner prescribed by laws on the privatization of state and municipal property.

\section{Methods}

The methodological basis of this study is a set of methods for the scientific knowledge of social processes, circumstances, and facts. The research is planned to be based on the following methodological principles: objectivity, determinism, historicism, integrity, complexity, systematicity, structurality, functionality, hierarchy, pluralism of explanation and understanding of law, and comparative studies.

The study is carried out through the methods of dialectical materialism as a fundamental tool in humanitarian research. As the main research method, the dialectical method of cognition is chosen, which involves the study of legal and social phenomena in their historical and logical relationship and interdependence. The authors use the methods of historicism and scientific objectivity, through which a comprehensive analysis of factual material is made considering the specific historical situation. The stages of such a historical process as privatization are identified, the features characteristic of a particular stage of privatization are considered in conjunction with an analysis of legal norms that have been in force in different historical periods, the current political situation, economic and social factors that influence privatization processes.

\section{Results And Discussion}

The essence of privatization relations is rather well described in foreign literature. For example, M. Peary in his monograph notes that state-owned enterprises neither have a profit motive, nor take into account consumer requests, etc., and privatized enterprises surpass state-owned enterprises in terms of their indicators [3]. A. Bordman and A. Weining adhere to a similar position [4]. That is, the emergence of privatization relations is a natural historical stage in the development of the state economy, which is aimed at developing market relations, creating competitive relations, and increasing the efficiency of state enterprises.

We will determine the initial moment of privatization relations in 
Russia. An analysis of legal literature suggests that there is no consensus on this issue. Most researchers and practitioners associate the beginning of privatization processes in Russia with the changes that have swept the country since the mid-80s of the XX century [5]. This is the so-called "creeping" and "free" privatization, that is, in fact, there were economic privatization relations in the country, but there were no legal norms regulating this phenomenon. It should be noted that legally the moment of the beginning of privatization processes in Russia is determined by the adoption of the Law of the Russian Federation No. 1531-1 of 03.07.1991 "On the privatization of state and municipal enterprises in the Russian Federation", the original text of which was published in the publication "Vedomosti SND and VS RSFSR" No. 27 of 04.07.1991 (hereinafter - the Privatization Law of 1991).

At the next stage of the study, it is necessary to consider the periodization of privatization relations, which is distinguished by various authors in the scientific literature. Periodization of privatization relations was considered by such scientists as Iu.N. Argunova, A.Kh. Trofimova, V.I. Ignatov, and others.

The opinion of Iu.N. Argunova consists in the fact that she distinguishes three stages: 1) the first stage begins with the adoption of the following regulatory legal acts: the Law "On Cooperation in the USSR" (1988), the Fundamentals of the Legislation of the USSR and the Union Republics on Lease (1989) and Regulations on joint-stock companies $(1990) ; 2)$ the second stage begins with the enactment of the Law of the RSFSR "On the privatization of state and municipal enterprises in the RSFSR"; 3) the third stage begins with the State program of privatization of state and municipal enterprises for 1992 [6].

If we consider the opinions of other authors, then most economistsresearchers and lawyers-researchers distinguish two stages of privatization: check (voucher) from June 1992 to 1994 and money from July 1, 1994. For example, the position of A.Kh. Trofimov is consistent with the general trend and consists in the fact that two stages of development of Russian legislation on privatization should be distinguished: 1) voucher privatization (1992-1994), which consisted in the redemption of 


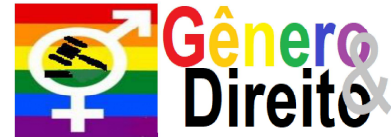

Periódico do Núcleo de Estudos e Pesquisas sobre Gênero e Direito Centro de Ciências Jurídicas - Universidade Federal da Paraíba V. 8 - No 06 - Ano 2019 - Special Edition ISSN | 2179-7137 | http://periodicos.ufpb.br/ojs2/index.php/ged/index state enterprises and their corporatization, etc.; 2) investment tenders for the sale of privatized stateowned objects (1993-1998) [7].

A study of the regulatory legal acts regulating the privatization processes in Russia shows that the most accurate will be the allocation of four historical stages: voucher stage (19921994); money stage (1993-1998); point stage (stage of "individual" projects) (2000-2003); and modern stage (from 2003 to the present).

We shall consider in more detail the features of the historical stages of the development of privatization relations and their legal regulation.

1) The voucher phase (the socalled "small privatization") is due to the adoption of such regulatory acts as the Privatization Law of 1991, the Decree of the President of the Russian Federation "On accelerating the privatization of state and municipal enterprises" of January 29, 1992, and the Decree of the President of the Russian Federation "On Introduction the system of privatization checks in the Russian Federation" of August 14, 1992. This stage is also called a check in the literature since the right of citizens to receive a share of state
195 property was certified by special security - a check. These regulations also established the mechanism for the initial distribution of shares between labor collectives and the state through vouchers with a nominal value of 10 thousand rubles. This voucher could be disposed of at one's choice freely: to sell in any way, or to buy shares of check investment funds.

During the implementation of the voucher phase of privatization, the following goals were set: "denationalization of the Russian economy, redistribution of private property rights; formation of a group of private owners; increase of the efficiency of Russian enterprises; development of a regulatory framework for the transfer of property rights from one entity to another; development of investment processes; and creation of competitive relations" [8].

It should be noted that during the voucher phase some implementation problems arose, they were mainly associated with the unwillingness of "immediate privatization and the high pace of privatization processes" [5]. Qualified personnel was required for carrying out privatization procedures, 


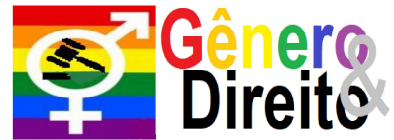

Periódico do Núcleo de Estudos e Pesquisas sobre Gênero e Direito Centro de Ciências Jurídicas - Universidade Federal da Paraíba V. 8 - No 06 - Ano 2019 - Special Edition ISSN | 2179-7137 | http://periodicos.ufpb.br/ojs2/index.php/ged/index thorough legal regulation of privatization procedures, and the necessary financial resources.

The end of the voucher phase dates back to the end of 1994. It should be noted that the official goals of privatization were not fully achieved, and if talking about socio-economic results, they were also negative, in particular, the political confrontation in society intensified, and internal party struggle began. In 1993, a scientific article was published by M. Boiko, A. Shleifer, R. Vaishni, which analyzed the Russian privatization program and concluded that at the moment this was the only way to achieve progress in corporate governance. Organizations should have an incentive to develop, that is, strive for efficiency in their own interests [9].

2) The monetary stage of privatization (the so-called "large privatization"). The completion of the voucher phase and the transition to the monetary one was due to the need to create a new privatization system, which was reflected in the program for 1994, approved by Decree of the President of the Russian Federation No. 1535 of July 22, 1994. The main purpose of this
196 document was to complete previous reforms and "establish secondary market securities, the approval of all necessary structures of a normal, civilized stock market in Russia" [10]. During this historical period, there was an increase in the number of private owners, which was supposed to stabilize the economic basis of market relations. The developers of the new privatization system have retained the basic methods of privatization, as well as defined specific privatization rules for enterprises with a state share of the property of more than $25 \%$. At this stage, investment funds began to play a special role, which could really participate in the management of joint-stock companies, as they could increase the share of one enterprise in their assets to $25 \%$.

The investigated stage of privatization can be characterized as a market since it is precisely the market mechanisms that have become dominant in the relations of the development of forms of ownership. The signs of this historical stage in the development of privatization relations include 1) the priority of private ownership over state property; 2) the emergence of new social groups that have financial and political 
influence due to their well-being. At the same stage, the Federal Law No. 123-FZ of July 21, 1997 "On the privatization of state property and the basics of the privatization of municipal property in the Russian Federation" is adopted, which was published in its original version in the "Collection of Legislation of the Russian Federation" No. 30 of July 28, 1997.

3) Point (stage of "individual" projects). Since September 9, 1999, the beginning of the point phase of privatization is being determined (adoption of Decree of the Government of the Russian Federation No. 1024 of 09.09.1999 "On the concept of state property management and privatization in the Russian Federation" and the valid Federal Law No. 178-FZ of 17.12-2001 "On the privatization of state and municipal property", published in its original version in the "Parlamentskaia Gazeta" No. 19 of 26.01.2002). We shall define the main goal of this stage. It consisted of the creation of a sustainable system of various forms of ownership. In these regulatory legal acts, the limits of competence of various public authorities for the management and disposal of state and municipal property were designated.
197

It should be noted that the legislation on the privatization of the stage in question is significantly different from the legislation of the previous stages due to a change in the target and conceptual attitudes.

The signs of this stage are: 1) the development of secondary privatization, in the framework of which the privatized property was transferred to the new owners; 2) privatization of state property by foreign companies bypassing legislation, and 3) the use of bankruptcy as a method of privatization.

4) The modern stage. Undoubtedly, the campaign on the privatization of the economy, carried out in the 1990s, cannot be compared with modern trends in privatization, however, legal issues are required for its successful implementation and effective state and public control over the course of the privatization campaign and its results.

It should be noted that in 20042008, the number of companies with a state or municipality share in capital, their participation in mergers and acquisitions increased.

The order of the Government of the Russian Federation No. 1805-r of November 30, 2009, approved a forecast 
plan (program) for privatizing federal property for 2010 and the main directions for privatizing federal property for 2011 and 2012. This document contained provisions on attracting extrabudgetary investments in the development of privatized industrial companies; on expanding the list of sectors (industries) for the purpose of privatization; focus on privatization of a number of largest (budget-forming) companies. Since 2011, three-year privatization programs have been implemented: for 2011-2013, for 20142016, for 2017-2019. Each program is characterized by its goals and objectives that were the priority at a certain stage.

\section{Summary}

The conducted historical and legal research allows us to conclude the following:

1) The moment of the beginning of the privatization processes in Russia is determined by the adoption on July 3, 1991, of the law "On the privatization of state and municipal enterprises in the RSFSR". Despite the fact that the need to change property relations arose in the 1980s, it was the 1991 privatization law that established the list and competence
198 of state bodies authorized to carry out privatization. This law established the procedure and methods for the privatization of state and municipal enterprises: sale of enterprises by competition, at auction, sale of shares (stocks) in the capital of an enterprise, redemption of leased property, and transformation of an enterprise into a joint-stock company.

2) The development of privatization, subject modern realities, can be divided into four stages: voucher privatization (1992-1994); money stage (1993-1998); point stage (stage of "individual" projects) (2000-2003); and modern stage (from 2003 to the present). Each of these stages was accompanied by appropriate legal regulation.

3) The review of the current legislation on privatization allows us to identify trends in the legal regulation of privatization processes at the present stage: equality of rights of buyers of state and municipal property in the process of privatization; the use of competitive methods for determining buyers of state and municipal property in the privatization process; compulsory retribution of alienation of state and 


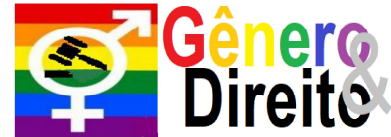

Sirginere

Periódico do Núcleo de Estudos e Pesquisas sobre Gênero e Direito Centro de Ciências Jurídicas - Universidade Federal da Paraíba V. 8 - No 06 - Ano 2019 - Special Edition ISSN | 2179-7137 | http://periodicos.ufpb.br/ojs2/index.php/ged/index

199

municipal property in the process of privatization.

\section{$5 \quad$ Conclusions}

The immediate goal of privatization at the initial stage was to create an effective, socially-oriented market economy, increase the activity of business entities, develop competition, etc. Due to the fact that the privatization process was accompanied by violations, both on the part of the federal government bodies and their authorized representatives, and by the heads of the privatized enterprises, this goal was not fully achieved, and the distribution of property was carried out among a limited circle of people.

At the present stage, there is a need to adjust the current legal regulation of privatization relations, identify the current goals and objectives of privatization, the forms of its implementation, taking into account the indicated trends.

\section{Acknowledgments}

The work is performed within the framework of the Russian Government Program of Competitive Growth of Kazan Federal University.
Kammerer J.A. Privatisierung. Typologie-Determinanten-RechtspraxisFolgen. Tubigen, 2001. Citation according to Kaidatizis A. A Typology of the Constitutional Limitations on Privatization // VIIth World Congress of International Association of Constitutional Law, Athens 11 - 15 June 2007. P. 3.

Kaidatizis A. A Typology of the Constitutional Limitations on Privatization // VIIth World Congress of International Association of Constitutional Law, Athens 11 - 15 June 2007. P. 1.

Pirie M. Privatization. Theory, Practice, and Choice. - Aldershot: Wildwood House, 1988. - 184 p.

Boardman A.E., Vining A.R. Ownership and Performance in Competitive Environments: a Comparison of the Performance of Private, Mixed and State-Owned Enterprises Journal of Law and Economics. 1989. Vol. 32. P. 29. 
Alekseev S.S. Ownership. Problems of the theory. - 3rd ed. - M., 2013. - P. 203.

Argunova Iu. N. Criminological analysis of legislation on the privatization of state and municipal property. In the book "Crime in Russia and the problems of the fight against it”. - M., 2001. - P. 111.

Trofimova A.Kh. Features of legal regulation of privatization of state and municipal property: Author's abstract, Candidate of Legal Sciences. - M., 2012. - P. 11.

Ignatov V.I. Privatization of state property in the Russian Federation: problems of legal regulation: Author's abstract, Candidate of Legal Sciences. M., 2002. - P. 19.

Boiko M., Shleifer A., R.V. Privatizing Russia // Brooking Papers on Economic Activity. - 1993. - №2. - P. 139192.

Podberezkin A., Streiaev S., Khokhlov O., Iastrebov Ia. From the history of privatization in Russia. - M.: Stupeni, 2014. - P. 65 